\title{
Making sense of the antisense transcripts in C9FTD/ALS
}

\author{
Peter K. Todd
}

Published online: 1 November 2013

(C) Springer-Verlag Berlin Heidelberg (outside the USA) 2013

In medicine, Occam's razor is employed to enforce diagnostic parsimony upon complicated cases. Stated simply, Occam's razor says that the single disease that best accounts for all of a patient's symptoms is likely to be the primary cause of all of them. In biomedical research, a similar logic is often applied, triggering searches for a single central pathogenic mechanism as the primary (or sole) pathway that causes a given disease. The rationale for this approach is clear: only when we know the one true cause of a disease can we know where to focus our efforts for therapeutic development. In this issue of Acta Neuropathologica, five new papers suggest that successful application of Occam's razor to the recently described C9-associated frontotemporal dementia and amyotrophic lateral sclerosis (C9FTD/ALS) is going to be a challenge.

C9FTD/ALS is a dominantly inherited intronic GGGGCC hexanucleotide repeat expansion in C9orf72, a neuronally expressed gene of unknown function [7, 20]. It accounts for a significant fraction of all inherited cases and $\sim 4 \%$ of sporadic cases of amyotrophic lateral sclerosis and frontotemporal dementia in Caucasian populations [7, 9]. Pathologically, patients exhibit multiple types of proteinaceous neuronal inclusions, including TDP-43 positive cytoplasmic aggregates as well as P62 and ubiquilin positive but TDP-43 negative cytoplasmic inclusions $[6,7,10$, $16,22,23]$. Additionally, neurons in patient tissues exhibit

\footnotetext{
P. K. Todd $(\square)$

Department of Neurology, University of Michigan,

Ann Arbor, MI 48109-2200, USA

e-mail: petertod@med.umich.edu

P. K. Todd

Veterans Health Administration Medical Center,

Ann Arbor, MI 48105, USA
}

nuclear RNA foci containing GGGGCC repeat transcripts [7].

Nucleotide repeat expansion disorders are thought to elicit toxicity via three non-exclusive mechanisms [19]. As DNA, repeats can alter local chromatin structure and impact RNA transcription in cis, leading to suppressed RNA and protein expression from the gene in which they reside [5]. Alternatively, transcribed repeats as RNA can bind to and sequester RNA-binding proteins and prevent them from performing their normal functions [17]. Lastly, translated repeats can alter the normal functions of the proteins in which they reside while also directly eliciting toxicity via alterations in proteostasis [24]. Two additional factors add complexity to the determination of which mechanism is at play in any given disorder. First, many repeats are bidirectionally transcribed, leading to two potentially toxic RNAs from any given repeat [15]. Second, many nucleotide repeats appear capable of triggering protein translation in the absence of an initiator AUG codon through a process known as "RAN Translation" [4].

In C9FTD/ALS, there is evidence for each of these potential pathogenic mechanisms. The GGGGCC repeat expansion is associated with a decrease in detectable amounts of multiple C9orf72 mRNA isoforms [7, 9]. In addition, multiple groups observe the appearance of GGGGCC RNA foci and a growing list of potential RNAbinding proteins that could be sequestered by this RNA await further characterization [13, 18, 25]. Earlier this year, two different groups demonstrated that RAN translation leads to production of three different dipeptide repeat containing proteins (Gly-Arg, Gly-Pro, and Gly-Ala) that form $\mathrm{P} 62$ positive aggregates observed in patients $[1,14]$.

The new papers published here provide further support for each of these possible disease mechanisms, while adding a new player to consider: toxicity elicited by production 
of an antisense transcript through the repeat. This CCCCGG repeat containing transcript triggers formation of neuronal and (less frequently) glial RNA foci in C9FTD/ALS patient tissues $[8,21]$. These foci are seen predominantly in the nucleus, but they can occur in the cytoplasm, suggesting that these transcripts could also be targets for RAN translation. Indeed, both Gendron et al. [8] and Mori et al. [12] demonstrate the presence of antisense-derived RAN translation products in all three reading frames, producing Arg-Pro, Gly-Pro, and Ala-Pro dipeptide repeat proteins. These antisense RAN products accumulate in P62 positive aggregates, just like the RAN products derived from GGGGCC sense transcripts. Interestingly, the presence of RNA foci and the RAN aggregates appears to be distinct (and potentially competing) events, such that the majority of neurons with sense or antisense RNA foci do not exhibit RAN-mediated inclusions and vice versa [8, 21]. Consistent with this observation, Mackenzie and colleagues find that the distribution of one particular RAN product within the CNS of C9FTD/ALS patients is similar across clinical phenotypes and is anti-correlated with both cytoplasmic TDP-43 aggregate formation and neurodegeneration [11]. As they wisely point out, this could indicate either that these aggregates are in fact protective or that production of C9RAN proteins is not a factor in pathogenesis.

Lastly, Belzil et al. [2] demonstrate that the local chromatin structure around the repeat is altered in both patient tissue samples and in blood from patients, with increased histone $\mathrm{H} 3$ and $\mathrm{H} 4$ tri-methylation in two neighboring $\mathrm{CpG}$ islands. These chromatin marks are typically associated with decreased transcription and they observe less mRNA in C9orf72 isoforms in patient samples and cells by RTPCR. Interestingly, they were able to reactivate transcription of the gene in patient-derived cells with demethylating agents.

So what should we make of all of this? First, the pathology is telling us that all of these processes do occur in the majority of patients with the clinical disease. What remains unclear is (1) which event (if any) is proximal in triggering neurodegeneration; (2) what components are necessary and sufficient to elicit toxicity and (3) what additive or synergistic interactions these components exhibit in disease pathogenesis. Early data suggest that both RNA alone and C9orf72 loss of function alone are capable of eliciting relevant phenotypes in simple model systems [3, 25]. However, the relevance of these findings in mammalian systems at expression levels seen in patients is less clear. In addition, teasing out the relative contributions of each transcript and each RAN product will be difficult, given our current inability to dissociate the production of these two components. Lastly, although one might anticipate that antisense transcripts and RAN translation products will be less abundant than their sense transcript counterparts, one must be cautious about dismissing even low level accumulation of potentially highly toxic molecules.

The corollary in clinical medicine to Occam's razor is known as Hickam's dictum, which states that "Patients can have as many diseases as they damn well please". Future studies will undoubtedly extend our understanding of how each of these different processes contributes to C9FTD/ALS disease pathogenesis individually. However, we may in the end need to accept that effects of the repeat on local chromatin structure as DNA, as a sink for GGGGCC and CCCCGG repeat binding proteins as RNA, and as different RAN protein products have additive (and perhaps synergistic) influences on disease biology. Such a messy reality will make development of effective therapeutics more difficult, but ignoring such a reality carries equal risk.

Acknowledgments Funding for this work was provided by the M-Cubed Initiative, the Department of Veterans Affairs (BLRD \#11212652), The NIH (K08NS069809 and P30-AG13283) and the Harris Professorship to PKT.

\section{References}

1. Ash PE, Bieniek KF, Gendron TF, Caulfield T, Lin WL, DejesusHernandez M, van Blitterswijk MM, Jansen-West K, Paul JW 3rd, Rademakers R, Boylan KB, Dickson DW, Petrucelli L (2013) Unconventional translation of C9ORF72 GGGGCC expansion generates insoluble polypeptides specific to c9FTD/ALS. Neuron 77(4):639-646. doi:10.1016/j.neuron.2013.02.004

2. Belzil VV, Bauer PO, Prudencio M, Gendron TF, Stetler CT, Yan IK, Pregent L, Daughrity L, Baker MC, Rademakers R, Boylan K, Patel TC, Dickson DW, Petrucelli L (2013) Reduced C9orf72 gene expression in c9FTD/ALS is caused by histone trimethylation, an epigenetic event detectable in blood. Acta Neuropathologica

3. Ciura S, Lattante S, Le Ber I, Latouche M, Tostivint H, Brice A, Kabashi E (2013) Loss of function of C9orf72 causes motor deficits in a zebrafish model of Amyotrophic Lateral Sclerosis. Ann Neurol. doi:10.1002/ana.23946

4. Cleary JD, Ranum LP (2013) Repeat-associated non-ATG (RAN) translation in neurological disease. Hum Mol Genet 22(R1):R45R51. doi: $10.1093 / \mathrm{hmg} / \mathrm{ddt} 371$

5. Coffee B, Zhang F, Warren ST, Reines D (1999) Acetylated histones are associated with FMR1 in normal but not fragile X-syndrome cells. Nat Genet 22(1):98-101. doi:10.1038/8807

6. Cooper-Knock J, Hewitt C, Highley JR, Brockington A, Milano A, Man S, Martindale J, Hartley J, Walsh T, Gelsthorpe C, Baxter L, Forster G, Fox M, Bury J, Mok K, McDermott CJ, Traynor BJ, Kirby J, Wharton SB, Ince PG, Hardy J, Shaw PJ (2012) Clinico-pathological features in amyotrophic lateral sclerosis with expansions in C9ORF72. Brain 135(Pt 3):751-764. doi:10.1093/ brain/awr365

7. DeJesus-Hernandez M, Mackenzie IR, Boeve BF, Boxer AL, Baker M, Rutherford NJ, Nicholson AM, Finch NA, Flynn H, Adamson J, Kouri N, Wojtas A, Sengdy P, Hsiung GY, Karydas A, Seeley WW, Josephs KA, Coppola G, Geschwind DH, Wszolek ZK, Feldman H, Knopman DS, Petersen RC, Miller BL, Dickson DW, Boylan KB, Graff-Radford NR, Rademakers R (2011) Expanded GGGGCC hexanucleotide repeat in noncoding 
region of C9ORF72 causes chromosome 9p-linked FTD and ALS. Neuron 72(2):245-256. doi:10.1016/j.neuron.2011.09.011

8. Gendron TF, Bieniek KF, Zhang YJ, Jansen-West K, Ash PE, Caulfield T, Daughrity L, Dunmore JH, Castanedes-Casey M, Chew J, Cosio DM, van Blitterswijk M, Lee WC, Rademakers R, Boylan KB, Dickson DW, Petrucelli L (2013) Antisense transcripts of the expanded C9ORF72 hexanucleotide repeat form nuclear RNA foci and undergo repeat-associated non-ATG translation in c9FTD/ALS. Acta Neuropathol. doi:10.1007/ s00401-013-1192-8

9. Gijselinck I, Van Langenhove T, van der Zee J, Sleegers K, Philtjens S, Kleinberger G, Janssens J, Bettens K, Van Cauwenberghe C, Pereson S, Engelborghs S, Sieben A, De Jonghe P, Vandenberghe R, Santens P, De Bleecker J, Maes G, Baumer V, Dillen L, Joris G, Cuijt I, Corsmit E, Elinck E, Van Dongen J, Vermeulen S, Van den Broeck M, Vaerenberg C, Mattheijssens M, Peeters K, Robberecht W, Cras P, Martin JJ, De Deyn PP, Cruts M, Van Broeckhoven C (2012) A C9orf72 promoter repeat expansion in a Flanders-Belgian cohort with disorders of the frontotemporal lobar degeneration-amyotrophic lateral sclerosis spectrum: a gene identification study. Lancet Neurol 11(1):5465. doi:10.1016/S1474-4422(11)70261-7

10. Hsiung GY, DeJesus-Hernandez M, Feldman HH, Sengdy P, Bouchard-Kerr P, Dwosh E, Butler R, Leung B, Fok A, Rutherford NJ, Baker M, Rademakers R, Mackenzie IR (2012) Clinical and pathological features of familial frontotemporal dementia caused by C9ORF72 mutation on chromosome 9p. Brain 135:709-722. doi:10.1093/brain/awr354

11. Mackenzie IR, Arzberger T, Kremmer E, Troost D, Lorenzl S, Mori K, Weng SM, Haass C, Kretzschmar HA, Edbauer D, Neumann M (2013) Dipeptide repeat protein pathology in C9ORF72 mutation cases: clinico-pathological correlations. Acta Neuropathol. doi:10.1007/s00401-013-1181-y

12. Mori K, Arzberger T, Grasser FA, Gijselinck I, May S, Rentzsch K, Weng SM, Schludi MH, van der Zee J, Cruts M, Van Broeckhoven C, Kremmer E, Kretzschmar HA, Haass C, Edbauer D (2013) Bidirectional transcripts of the expanded C9orf72 hexanucleotide repeat are translated into aggregating dipeptide repeat proteins. Acta Neuropathol. doi:10.1007/s00401-013-1189-3

13. Mori K, Lammich S, Mackenzie IR, Forne I, Zilow S, Kretzschmar H, Edbauer D, Janssens J, Kleinberger G, Cruts M, Herms J, Neumann M, Van Broeckhoven C, Arzberger T, Haass C (2013) hnRNP A3 binds to GGGGCC repeats and is a constituent of p62-positive/TDP43-negative inclusions in the hippocampus of patients with C9orf72 mutations. Acta Neuropathol 125(3):413423. doi:10.1007/s00401-013-1088-7

14. Mori K, Weng SM, Arzberger T, May S, Rentzsch K, Kremmer E, Schmid B, Kretzschmar HA, Cruts M, Van Broeckhoven C, Haass C, Edbauer D (2013) The C9orf72 GGGGCC repeat is translated into aggregating dipeptide-repeat proteins in FTLD/ALS. Science 339(6125):1335-1338. doi:10.1126/science.1232927

15. Moseley ML, Zu T, Ikeda Y, Gao W, Mosemiller AK, Daughters RS, Chen G, Weatherspoon MR, Clark HB, Ebner TJ, Day JW, Ranum LP (2006) Bidirectional expression of CUG and CAG expansion transcripts and intranuclear polyglutamine inclusions in spinocerebellar ataxia type 8. Nat Genet 38(7):758-769. doi: $10.1038 / \operatorname{ng} 1827$

16. Murray ME, DeJesus-Hernandez M, Rutherford NJ, Baker M, Duara R, Graff-Radford NR, Wszolek ZK, Ferman TJ, Josephs
KA, Boylan KB, Rademakers R, Dickson DW (2011) Clinical and neuropathologic heterogeneity of c9FTD/ALS associated with hexanucleotide repeat expansion in C9ORF72. Acta Neuropathol 122(6):673-690. doi:10.1007/s00401-011-0907-y

17. O'Rourke JR, Swanson MS (2009) Mechanisms of RNA-mediated disease. J Biol Chem 284(12):7419-7423. doi:10.1074/jbc. R800025200

18. Reddy K, Zamiri B, Stanley SY, Macgregor RB Jr, Pearson CE (2013) The disease-associated r(GGGGCC)n repeat from the C9orf72 gene forms tract length-dependent uni- and multimolecular RNA G-quadruplex structures. J Biol Chem 288(14):98609866. doi:10.1074/jbc.C113.452532

19. Renoux AJ, Todd PK (2012) Neurodegeneration the RNA way. Prog Neurobiol 97(2):173-189. doi:10.1016/j.pneurobio.2011. 10.006

20. Renton AE, Majounie E, Waite A, Simon-Sanchez J, Rollinson S, Gibbs JR, Schymick JC, Laaksovirta H, van Swieten JC, Myllykangas L, Kalimo H, Paetau A, Abramzon Y, Remes AM, Kaganovich A, Scholz SW, Duckworth J, Ding J, Harmer DW, Hernandez DG, Johnson JO, Mok K, Ryten M, Trabzuni D, Guerreiro RJ, Orrell RW, Neal J, Murray A, Pearson J, Jansen IE, Sondervan D, Seelaar H, Blake D, Young K, Halliwell N, Callister JB, Toulson G, Richardson A, Gerhard A, Snowden J, Mann D, Neary D, Nalls MA, Peuralinna T, Jansson L, Isoviita VM, Kaivorinne AL, Holtta-Vuori M, Ikonen E, Sulkava R, Bena$\operatorname{tar}$ M, Wuu J, Chio A, Restagno G, Borghero G, Sabatelli M, Heckerman D, Rogaeva E, Zinman L, Rothstein JD, Sendtner M, Drepper C, Eichler EE, Alkan C, Abdullaev Z, Pack SD, Dutra A, Pak E, Hardy J, Singleton A, Williams NM, Heutink P, PickeringBrown S, Morris HR, Tienari PJ, Traynor BJ (2011) A hexanucleotide repeat expansion in C9ORF72 is the cause of chromosome 9p21-linked ALS-FTD. Neuron 72(2):257-268. doi:10.1016/j. neuron.2011.09.010

21. Mizielinska S, Lashley T, Norona FE, Clayton EL, Ridler CE, Fratta P, Isaacs AM (2013) C9orf72 frontotemporal lobar degeneration is characterised by frequent neuronal sense and antisense RNA foci. Acta Neuropathol. doi:10.1007/s00401-013-1200-Z

22. Snowden JS, Rollinson S, Thompson JC, Harris JM, Stopford CL, Richardson AM, Jones M, Gerhard A, Davidson YS, Robinson A, Gibbons L, Hu Q, DuPlessis D, Neary D, Mann DM, Pickering-Brown SM (2012) Distinct clinical and pathological characteristics of frontotemporal dementia associated with C9ORF72 mutations. Brain 135(Pt 3):693-708. doi:10.1093/brain/awr355

23. Stewart H, Rutherford NJ, Briemberg H, Krieger C, Cashman N, Fabros M, Baker M, Fok A, DeJesus-Hernandez M, Eisen A, Rademakers R, Mackenzie IR (2012) Clinical and pathological features of amyotrophic lateral sclerosis caused by mutation in the C9ORF72 gene on chromosome 9p. Acta Neuropathol 123(3):409-417. doi:10.1007/s00401-011-0937-5

24. Williams AJ, Paulson HL (2008) Polyglutamine neurodegeneration: protein misfolding revisited. Trends Neurosci 31(10):521528. doi:10.1016/j.tins.2008.07.004

25. Xu Z, Poidevin M, Li X, Li Y, Shu L, Nelson DL, Li H, Hales CM, Gearing M, Wingo TS, Jin P (2013) Expanded GGGGCC repeat RNA associated with amyotrophic lateral sclerosis and frontotemporal dementia causes neurodegeneration. Proc Natl Acad Sci USA 110(19):7778-7783. doi:10.1073/p nas. 1219643110 